\title{
Seasonal dynamics on nutritive value, chemical estimates and in vitro dry matter degradability of some woody species found in rangelands of South Africa
}

\author{
Khuliso Emmanuel Ravhuhali • Ntokozo Happy Msiza () - Humbelani Silas Mudau
}

Received: 9 April 2021/ Accepted: 3 September 2021 / Published online: 13 November 2021

(C) The Author(s) 2021

\begin{abstract}
Unlocking browse species in semi-arid regions can be a key to improving the livestock productivity. The research was conducted to assess the browse species variation in chemical composition and in vitro dry matter degradability as influenced by seasonal (summer and winter) changes. Leaves from ten randomly selected browsable trees from sixteen species (Vachellia karroo, Senegalia nigrescens, Vachellia nilotica, Balanites maughamii, Berchemia discolor, Berchemia zeyheri, Bridelia mollis, Combretum collinum, Combretum imberbe, Dalbergia melanoxylon, Dichrostachys cinerea, Grewia monticola, Grewia occidentalis, Melia azedarach, Ormocarpum kirkii and Ziziphus mucronata) were harvested before defoliation from the site in two seasons (summer and winter) and dried at room temperature and then ground for analysis. Two-way analysis was used to analyse chemical composition and in vitro ruminal dry matter degradability. Melia azedarach (343.7 g/kg DM) had the highest $(p<0.0001) \mathrm{CP}$ content in summer. In
\end{abstract}

K. E. Ravhuhali · N. H. Msiza $(\varangle) \cdot$ H. S. Mudau Department of Animal Science, School of Agricultural Sciences, Faculty of Natural and Agricultural Sciences, North West University, Mmabatho 2735, South Africa e-mail: ntokozohmsiza@gmail.com

K. E. Ravhuhali · N. H. Msiza · H. S. Mudau Food Security and Safety Niche Area, School of Agricultural Sciences, Faculty of Natural and Agricultural Sciences, North West University, Mmabatho 2735, South Africa winter, B. maughamii (210.3 $\mathrm{g} / \mathrm{kg} \mathrm{DM})$ had the highest $(p<0.05)$ crude protein content. Combretum collinum $(2.90 \mathrm{Mcal} / \mathrm{kg})$ had a highest $(p<0.0001)$ metabolizable energy value in summer. Bridelia mollis, $B$. maughamii, B. discolor, C. collinum, C. imberbe, O. kirkii, S. nigrescens, $V$. nilotica, G. occidentalis and $B$. zeyheri had the same $(p>0.0001)$ dry matter degradability (DMD) 48 values across two seasons. In both seasons, most of these browse species have the potential to supplement low quality natural grasses because they go beyond the minimum requirement of protein and have coherent amounts of fibre concentration. There is a need to assess the bioactive compounds found in these browse species for the amelioration and also to maximize browsing of these species.

Keywords Ruminants - Crude protein - Browse Semi-arid $\cdot$ Season

\section{Introduction}

Livestock play a significant role in rural livelihoods and the economies of developing countries (Enahoro et al., 2019), and these livestock depend on rangelands mostly in semi-arid areas. Browse species as forage are used in the feeding of domestic (e.g., goats) and wilderness ruminants and are generally regarded as the cheapest source of nutrients for these ruminants. 
The relationship between season and plants and livestock has been observed around the world especially in semi-arid areas (Hassen et al., 2017; Mudzengi et al., 2020; Castro et al., 2021). This is due to the fact that climatic conditions in semi-arid regions are likely to increase the competition of resources among livestock (Mudzengi et al., 2020). Due to seasonal variation, plant growth and accumulation of leaves can be affected negatively or postively which will either lead to a shortage or an abundance of available forage for livestock (Hassen et al., 2017). For example, during the drought season herbaceous layer tends to deteriorate its nutritional content and livestock happen to rely on browse species for nutritional needs. This will normally have an influence on ruminal fermentation of substrates, and the ruminants exposed on these low-quality forages will have difficulties meeting their maintenance requirements on certain seasons leading to low feed intake and ruminal fermentation on ruminants and this may lead to poor growth rate (Ravhuhali et al., 2011). The browse species are useful and inexpensive source of nutrients for livestock especially during drought seasons and they can be the alternative to commercial feed resources in most communal areas.

The nutritional value of forage depends on the amount of proteins, the concentration of acid detergent lignin and digestible carbohydrates, and these nutrients normally vary with seasons. Ravhuhali et al. (2020) stressed that leaves of many browse species have crude protein concentration of above $10 \%$. With the comparison to conventional diets, browse leaves are known to have the potential to be used as protein supplements to diets that have low protein and fermentable energy values (El Hassan et al., 2000). Apart from the crude protein content of plants species, the chemical estimates such as dry matter digestibility (DMDigest), total digestible nutrients (TDN), relative feeding values (RFV), digestible energy and metabolisable energy vary with the kind of ruminant livestock and are of great importance for the animal's nutritional demands (NRC, 1985). Forages with high concentration of lignin are also known to have a low TDN than other fodder crops. The chemical estimates which are related to chemical composition varies widely among the woody species. Dry matter digestibility of browse species ranges from 58 to 75\% (Boufennara et al., 2012; Mokoboki et al., 2019), total digestible nutrients of $50-65 \%$ and relative feeding value of up to $95 \%$ (Mokoboki et al. 2019).

However, in spite of their abundance, many wild browse species have been generally undervalued mainly because of insufficient knowledge about their potential feeding value in different seasons. Exploring the nutritional value of the resources available in different seasons for browsing livestock is considered as one of the keys to the efficient and sustainable production of animals (Minson, 1990). Some of the ligneous species studied here are consumed to a certain degree by small ruminants (Kababya et al., 1998). There is a need for a laboratory analysis for better understanding nutritional composition and utilization of these indigenous browse woody species. Therefore, the objective of the study was to assess the effect of season and species on nutritive value and in vitro ruminal dry matter degradability of browse species found in the selected rangelands areas in semiarid South Africa, while hypothesizing that there would be a variation in the parameters.

\section{Materials and methods}

Harvesting site and leaves

The study was carried out at Thulamela Local Municipality (Limpopo) with a very high number of indigenous ruminants (goats and cattle) that rely entirely on rangelands. The tree species were harvested in communal areas of Thulamela Municipality around Vhembe District in Limpopo province. The communal areas (Makuya and Lamvi S 22 39'49.85" and $\mathrm{E} 30^{\circ} 45^{\prime} 21.88$ ) are located in the 40 to $50 \mathrm{~km}$ from Kruger National Park. In summer time annual temperatures is $34{ }^{\circ} \mathrm{C}$ and the winter time is $13{ }^{\circ} \mathrm{C}$ (SAWS, 2020). In December and early June 2019 leaves (ten tree per species) from randomly selected sixteen trees species (Vachellia karroo; Senegalia nigrescens; Vachellia nilotica; Balanites maughamii; Berchemia discolor; Berchemia zeyheri; Bridelia mollis; Combretum collinum; Combretum imberbe; Dalbergia melanoxylon; Dichrostachys cinerea subsp. africana; Grewia monticola; Grewia occidentalis; Melia azedarach; Ziziphus mucronata and Ormocarpum kirkii) were harvested before defoliation from the site by hand at a height of not more than $1.5 \mathrm{~m}$. The samples were harvested from the same 
trees in the same area for summer and winter. Each of the samples was stored separately in labelled brown paper bag. Samples were dried at room temperature and transferred to the oven set at a temperature of $60{ }^{\circ} \mathrm{C}$ overnight, after which they were ground to pass a $1 \mathrm{~mm}$ sieve and kept in a tight plastic container for chemical analyses. Harvested species were also grouped according to growth form and herbivory (Table 1). Van Wyk et al. (2012) book was used to identify the species. Information on the woody species utilization was obtained from local farmers and herders from the respective grazing communal areas.

\section{Chemical analyses}

Organic matter (OM), ash and nitrogen content (Micro-Kjedahl method) were determined (AOAC, 1999). Crude protein was calculated by multiplying nitrogen value with a factor 6.25. Fibre fraction (neutral detergent fibre and acid detergent fibre) was determined using ANKOM $^{2000}$ according to Van Soest et al. (1991) using ANKOM F57 bags. Acid detergent fibre (ADF) bags were soaked on $72 \%$ of sulphuric acid for ADL determination. The formula used to predict total digestible nutrients (TDN) was
$82.38-(0.7515 \times A D F)$ as described by Bath \& Marble (1989). The formula for dry matter digestibility was DMDigest $\%=88.9-(0.779 \times \% A D F)$. Dry matter intake (DMI) was calculated using the NDF concentration and $2.5 \%$ of animal body weight as described by Mertens (2002). Relative feed value (RFV) was calculated using the following method: $\mathrm{RFV}=(\%$ DMDigest $\times \%$ DMI $) / 1.29$ (Jeranyama \& Garcia, 2004). The equation for estimated digestible energy $(\mathrm{DE} \mathrm{Mcal} / \mathrm{kg})=0.27+0.0428($ DMDigest $\%)$ as reported by Fonnesbeck et al. (1984). DE values were converted to ME using the formula reported by Khalil et al. (1986) ME (Mcal/ $\mathrm{kg})=0.821 \times \mathrm{DE}(\mathrm{Mcal} / \mathrm{kg})$.

\section{In vitro ruminal degradation}

The in vitro ruminal DM degradability of leaf samples was determined using the DaisyII incubator consisting of a thermostatic chamber $\left(39^{\circ} \mathrm{C}\right)$ with four rotating jars according to ANKOM Technology for in vitro true digestibility. Ground samples were weighed into ANKOM F57 bags (0.45-0.5 g), heat sealed and placed in the digestion jars. Two buffer solutions were prepared in advance and combined at a ratio of 1:5,

Table 1 Scientific and common names, growth form, herbivory and browse form of browse species identified in semi-arid areas of Limpopo province

\begin{tabular}{|c|c|c|c|c|}
\hline Species & Common name & Growth form & Herbivores & PPP \\
\hline Vachellia karroo & Sweet thorn & Shrub & Cattle and goats & $\mathrm{L}, \mathrm{P}$ \\
\hline Senegalia nigrescens & Knob thorn & Tree & Cattle and goats & $\mathrm{L}, \mathrm{P}$ \\
\hline Vachellia nilotica & Scented pod & Tree & Goats and game & $\mathrm{L}, \mathrm{P}$ \\
\hline Balanites maughamii & Torchwood & Tree & Game and cattle and goats & $\mathrm{L}, \mathrm{F}, \mathrm{S}$ \\
\hline Berchemia discolor & Brown ivory & Tree & Game and cattle and goats & $\mathrm{L}, \mathrm{F}, \mathrm{S}$ \\
\hline Berchemia zeyheri & Red ivory & Tree & Game and cattle and goats & $\mathrm{L}, \mathrm{F}, \mathrm{S}$ \\
\hline Bridelia mollis & Velvet Sweet-Berry & Shrub & Cattle, goats and game & $\mathrm{L}, \mathrm{F}, \mathrm{T}$ \\
\hline Combretum collinum & Weeping bush willow & Tree & Cattle and goats, game & $\mathrm{L}$ \\
\hline Combretum imberbe & Lead wood & Tree & Cattle and goats & $\mathrm{L}$ \\
\hline Dalbergia melanoxylon & African black wood & Shrub & Cattle, goats and game & $\mathrm{F}, \mathrm{L}$ \\
\hline Dichrostachys cinerea subsp. africana; & Sickle bush & Shrub & Goat & $\mathrm{L}, \mathrm{P}$ \\
\hline Grewia monticola & Silver raisin & Shrub & Goats & $\mathrm{L}$ \\
\hline Grewia occidentalis & Four corners & Shrub & Goats & $\mathrm{L}$ \\
\hline Melia azedarach & China berry & Tree & Cattle and goats & $\mathrm{L}$ \\
\hline Ormocarpum kirkii & Caterpillar bush & Shrub & Goats and game & $\mathrm{L}$ \\
\hline Ziziphus mисronata & Buffalo thorn & Tree & Cattle and goats & $\mathrm{L}, \mathrm{P}$ \\
\hline
\end{tabular}

$P P P=$ preferred plant parts; $L=$ leaves; $F=$ fruits, $P=$ pods; $S=$ seeds; $T=$ twigs 
according to ANKOM Technology, and $1600 \mathrm{~mL}$ of the combined buffer was transferred to each of the four jars and warmed. Rumen inoculum was collected in the morning before feeding from a ruminally cannulated Bonsmara cow (metabolic weight $=550 \mathrm{~kg}$ ). The cannulated cow was kept in a stall and had access to Buffalo grass and Lucerne. Strained rumen fluid was held at $39^{\circ} \mathrm{C}$ under a stream of carbon dioxide gas. ANKOM F57 bags containing samples, were inoculated by adding $400 \mathrm{~mL}$ of rumen inoculum to each digestion jar containing buffer. Each jar was purged with $\mathrm{CO}_{2}$ before being covered and placed in the incubation chamber. Filter bags were withdrawn at 24, 36 and $48 \mathrm{~h}$ after inoculation and were washed with cold water for $20 \mathrm{~min}$ and dried for $12 \mathrm{~h}$ at $105{ }^{\circ} \mathrm{C}$. The ethical approval certificate was acquired from the North West University Animal Research Ethic Committee (NWU-00126-13-A9). The animal was cared for according to the guidelines of the institution and Federation of Animal Science Societies (FASS, 2010) for the use of agricultural livestock in teaching and research activities.

Statistical analysis

Browse species data were analysed using a two-way factorial treatment design in a completely randomised design SAS (2010). The general linear model used was as follows:

$Y i j k=u+B i+S j+(B x S) i j+\varepsilon i j k$

where $u$ was the overall mean, $S$ was the effect of variation between species; $S j$ was effect of season; $B x S$ was the interaction effect, and cijk is random error. The probability of difference (PDIFF) option in the LS means statement of SAS was used to compare the least square means.

\section{Results}

The differences $(p<0.0001)$ were observed on the effect of species, season and the interaction between species and season on ash, OM, CP, ADF, ADL, DMDigest, TDN, DE, ME and DMD36 (Tables 2, 3, 4 and 5). The significance differences were observed on the effect of species and season on NDF, DMI and $\mathrm{RFV}$. The crude protein content ranged from $149 \mathrm{~g} / \mathrm{kg}$ DM in B. mollis to $343.7 \mathrm{~g} / \mathrm{kg} \mathrm{DM}$ in M. azedarach in the summer season (Table 2), and ranges from $133 \mathrm{~g} /$ $\mathrm{kg} \mathrm{DM}$ in Z. mucronata to $210.3 \mathrm{~g} / \mathrm{kg} \mathrm{DM}$ in $B$. maughamii in the winter season. Dichrostachy cinerea, B. discolor, C. collinum, D. melanoxylon, G. monticola, C. imberbe, V. karroo, M. azedarach, $V$. nigrescens and B. zeyheri had higher $(p<0.0001$; $F=9187.6) \mathrm{CP}$ content in summer than the same species in winter. In Table $3 \mathrm{NDF}$ content ranged from $392 \mathrm{~g} / \mathrm{kg}$ DM in M. azedarach to $572 \mathrm{~g} / \mathrm{kg} \mathrm{DM}$ in the summer, and in winter it ranged from $283 \mathrm{~g} / \mathrm{kg} \mathrm{DM}$ in B. zeyheri to $576 \mathrm{~g} / \mathrm{kg} \mathrm{DM}$ in V. karroo. With an exception to D. cinerea, G. occidentalis, V. karroo and $M$. azedarach; all other browse species had higher $(p<0.0001 ; F=8.6)$ NDF in summer when compared to the same species in winter. Summer season greatly influenced ( $p<0.0001 ; F=45.2)$ ADL content of $B$. mollis, $(502.3 \mathrm{~g} / \mathrm{kg} \mathrm{DM}) ; S$. nigrescens (321.0 g/kg DM), V. nilotica (325.2 g/ $\mathrm{kg} \mathrm{DM)} \mathrm{while}$ in winter D. cinerea $(355.8 \mathrm{~g} / \mathrm{kg} \mathrm{DM})$ had the highest $(p<0.0001 ; F=502.7)$ ADL content. Bridelia mollis, B. maughamii, D. melanoxylon; C. imberbe, $V$. karroo, O. kirkii, M. azedarach, S. nigrescens; V. nilotica, G. occidentalis and B. zeyheri had higher $(p<0.0001 ; F=502.7)$ ADL content in summer than the same species in the winter season.

For chemical estimates predictions in Table 4, $C$. collinum had the highest $(p<0.0001 ; F=227.8)$ DMDigest $\%$ in summer. Within each species, in summer D. cinerea, B. discolor, D. melanoxylon, $C$. collinum; C. imberbe, G. monticola, V. karroo; $O$. kirkii, M. azedarach, V. nilotica; and Z. mucronata had the highest $(p<0.0001 ; F=227.8)$ dry matter digestibility as compared to winter on the same species.

In summer, $C$. collinum had the highest $(p<0.0001 ; F=11.4)$ TDN value and $D$. melanoxylon had higher $(p<0.0001 ; F=11.4)$ TDN in winter.

The ME content ranged from $2.1 \mathrm{Mcal} / \mathrm{kg}$ in $G$. monticola and $S$. nigrescens to 2.9 in C. collinum in the summer season and $1.9 \mathrm{Mcal} / \mathrm{kg}$ in $D$. cinerea to 2.8 $\mathrm{Mcal} / \mathrm{kg}$ in $D$. melanoxylon in the winter season (Table 5). In Table 6 B. discolor; B. zeyheri and $O$. kirkii had better $(p<0.0001 ; F=11.3)$ DMD values after $36 \mathrm{~h}$ withdrawal period in winter. Dichrostachys cinerea and G. monticola had the least $(p<0.0001$; $F=11.3$ ) DMD36 values post 36-h withdrawal period in winter samples. Bridelia mollis, B. discolor, $C$. collinum, $C$. imberbe, $O$. kirkii, $S$. nigrescens, $V$. nilotica, G. occidentalis and B. zeyheri had the same 
Table 2 Effect of species and season on ash $(\mathrm{g} / \mathrm{kg}$ $\mathrm{DM})$, organic matter $(\mathrm{g} / \mathrm{kg}$ $\mathrm{DM})$ and crude protein $(\mathrm{g} /$ $\mathrm{kg}$ DM) on browse species found in semi-arid rangelands of South Africa

abcdefghijklm Shared lower case superscript letters within a column indicates a non-significant difference between browse species $(p>0.05)$

$\mathrm{AB}$ Shared lower case superscript letters within a row indicates a nonsignificant difference between seasons $(p>0.05) ; O M$, organic matter; $C P$, crude protein; $S E$, standard error

\begin{tabular}{|c|c|c|c|c|c|c|}
\hline & Ash & & $\mathrm{OM}$ & & $\mathrm{CP}$ & \\
\hline Species & Summer & Winter & Summer & Winter & Summer & Winter \\
\hline B. mollis & $55.5^{\mathrm{hB}}$ & $81.3^{\mathrm{hA}}$ & $885.9^{\mathrm{cA}}$ & $869.1^{\mathrm{cB}}$ & $148.6^{\mathrm{mB}}$ & $198.7^{\mathrm{bA}}$ \\
\hline D. cinerea & $53.5^{\mathrm{hiB}}$ & $80.3^{\mathrm{hA}}$ & $892.9^{\mathrm{abA}}$ & $866.2^{\mathrm{cB}}$ & $202.9^{\mathrm{efA}}$ & $156.6^{\mathrm{hB}}$ \\
\hline B. maughamii & $111.8^{\mathrm{aA}}$ & $69.1^{\mathrm{jB}}$ & $851.4^{\mathrm{gB}}$ & $874.9^{\mathrm{bA}}$ & $202.6^{\mathrm{fB}}$ & $210.3^{\mathrm{aA}}$ \\
\hline B. discolor & $63.7^{\mathrm{fB}}$ & $106.6^{\mathrm{dA}}$ & $889.3^{\mathrm{bcA}}$ & $848.5^{\mathrm{deB}}$ & $231.8^{\mathrm{bA}}$ & $195.5^{\mathrm{cB}}$ \\
\hline C. collinum & $53.6^{\mathrm{hiB}}$ & $58.4^{1 \mathrm{~A}}$ & $895.4^{\mathrm{aA}}$ & $895.2^{\mathrm{aA}}$ & $178.9^{\mathrm{hA}}$ & $163.7^{\mathrm{gB}}$ \\
\hline D. melanoxylon & $50.3^{\mathrm{jkB}}$ & $143.0^{\mathrm{bA}}$ & $896.5^{\mathrm{aA}}$ & $812.5^{\mathrm{fB}}$ & $210.3^{\mathrm{dA}}$ & $172.4^{\mathrm{eB}}$ \\
\hline G. monticola & $62.8^{\mathrm{fgB}}$ & $70.5^{\mathrm{ijA}}$ & $879.2^{\mathrm{dA}}$ & $877.7^{\mathrm{bA}}$ & $167.0^{\mathrm{jA}}$ & $147.8^{\mathrm{jB}}$ \\
\hline C. imberbe & $52.2^{\mathrm{ijB}}$ & $57.5^{1 \mathrm{~A}}$ & $896.7^{\mathrm{aA}}$ & $893.4^{\mathrm{aA}}$ & $163.1^{\mathrm{kA}}$ & $147.4^{\mathrm{jB}}$ \\
\hline V. karroo & $55.8^{\mathrm{hB}}$ & $72.7^{\mathrm{iA}}$ & $893.7^{\mathrm{abA}}$ & $876.3^{\mathrm{bB}}$ & $220.7^{\mathrm{cA}}$ & $145.5^{\mathrm{kB}}$ \\
\hline O. kirkii & $70.5^{\mathrm{eB}}$ & $99.9^{\mathrm{fA}}$ & $874.6^{\mathrm{deA}}$ & $849.4^{\mathrm{dB}}$ & $159.2^{1 \mathrm{~B}}$ & $167.8^{\mathrm{fA}}$ \\
\hline M. azedarach & $100.4^{\mathrm{bB}}$ & $163.0^{\mathrm{aA}}$ & $853.8^{\mathrm{gA}}$ & $793.2^{\mathrm{gB}}$ & $343.7^{\mathrm{aA}}$ & $139.4^{1 \mathrm{~B}}$ \\
\hline S. nigrescens & $60.4^{\mathrm{gB}}$ & $66.1^{\mathrm{kA}}$ & $879.2^{\mathrm{dA}}$ & $875.0^{\mathrm{bA}}$ & $158.2^{1 \mathrm{~A}}$ & $152.8^{\mathrm{iB}}$ \\
\hline$V$. nilotica & $48.2^{\mathrm{kB}}$ & $91.3^{\mathrm{gA}}$ & $895.4^{\mathrm{aA}}$ & $867.1^{\mathrm{cB}}$ & $185.1^{\mathrm{gB}}$ & $192.4^{\mathrm{dA}}$ \\
\hline G. occidentalis & $82.6^{\mathrm{cA}}$ & $81.6^{\mathrm{hA}}$ & $861.3^{\mathrm{fA}}$ & $864.1^{\mathrm{cA}}$ & $203.9^{\mathrm{eA}}$ & $167.6^{\mathrm{fB}}$ \\
\hline Z. mucronata & $73.7^{\mathrm{dB}}$ & $103.3^{\mathrm{eA}}$ & $870.4^{\mathrm{eA}}$ & $843.5^{\mathrm{eB}}$ & $201.9^{\mathrm{fA}}$ & $132.8^{\mathrm{mB}}$ \\
\hline B. zeyheri & $71.3^{\mathrm{deB}}$ & $125.7^{\mathrm{cA}}$ & $869.56^{\mathrm{eA}}$ & $817.6^{\mathrm{fB}}$ & $169.8^{\mathrm{iA}}$ & $146.9^{\mathrm{jB}}$ \\
\hline SE & 1.05 & & 1.98 & & 0.41 & \\
\hline
\end{tabular}

$(p>0.0001 ; F=5.9)$ DMD48 values across two seasons.

\section{Discussion}

\section{Chemical composition of browse species}

Browse plants remain the major source of feed during the period of scarcity because they are capable of surviving and retaining most of their nutritional value during the dry season in most arid and semi-arid regions (Aruwayo \& Adeleke, 2019). This qualifies them to be an alternative source of feed for ruminants as they are also easily accessible to farmers in communal areas who are financially constrained to buy commercial feeds. The browse species are diverse and have numerous fodder components which include leaves (green/brown), twigs, flowers and fruits of which have a much longer period of availability throughout all seasons. Chemical composition differences have been noted among different African vegetation types in semi-arid areas (Nsubuga et al., 2020). In this study a wide variation was noted among browse species in all parameters measured which is in line with Abebe et al. (2012). The current study revealed that, the ash concentration was better in winter than summer, with a range between 48 and $163 \mathrm{~g} / \mathrm{kg}$ DM. These results are in line with those reported by Aganga et al. (2005) (32.5-95.8 g/kg DM). The summer result on $Z$. mucronata is higher than the one reported by Ravhuhali et al. (2020) (39.4 g/kg DM). Therefore, the high ash content found in these species gives an overall representation of the mineral content (organic) present in the feed material that is essential for improving growth in animals (Msiza et al., 2021). Seasonal change is vital in the overall availability of forage for animal consumption, especially during the months when plant growth is less active. Plant growth tends to be slower in the winter season because of the negative effect of low ambient temperatures on growth (Hassen et al., 2007), thus low rainfall (a limiting factor) and other climatic conditions impose additional constrains for the process of photosynthesis to take place, therefore less forage yield is produced and CP content is likely to be lower. From this study M. azedarach in the summer (343.7 $\mathrm{g} / \mathrm{kg}$ DM) season was higher than that of Mokoboki et al. (2019) (206.7 g/kg DM) in the same season. Berchemia discolor species recorded a $\mathrm{CP}$ content of $231.8 \mathrm{~g} / \mathrm{kg} \mathrm{DM}$ (summer) and $195.5 \mathrm{~g} / \mathrm{kg}$ DM (winter). These results were comparable to the one reported by Osuga et al. (2012) (195 g/kg DM). In this study all the browse species had CP 
Table 3 Effect of species and season on neutral and acid detergent fibres (NDF, ADF, g/kg DM) and acid detergent lignin (ADL, $\mathrm{g} / \mathrm{kg} \mathrm{DM}$ ) of browse species found in semi-arid rangelands of South Africa

\begin{tabular}{|c|c|c|c|c|c|c|}
\hline & NDF & & $\mathrm{ADF}$ & & ADL & \\
\hline Species & Summer & Winter & Summer & Winter & Summer & Winter \\
\hline B. mollis & $447.9^{\text {efgA }}$ & $356.2^{\mathrm{deB}}$ & $395.9^{\mathrm{bA}}$ & $334.2^{\mathrm{deB}}$ & $321.6^{\mathrm{aA}}$ & $268.3^{\mathrm{dB}}$ \\
\hline D. cinerea & $423.7^{\mathrm{fgB}}$ & $522.4^{\mathrm{abA}}$ & $243.3^{\mathrm{gB}}$ & $433.6^{\mathrm{bA}}$ & $234.9^{\mathrm{eB}}$ & $355.8^{\mathrm{aA}}$ \\
\hline B. maughamii & $520.5^{\mathrm{abcdA}}$ & $397.8^{\mathrm{cdB}}$ & $390.7^{\mathrm{bA}}$ & $273.3^{\mathrm{hiB}}$ & $202.1^{\mathrm{hA}}$ & $186.9^{\mathrm{hB}}$ \\
\hline B. discolor & $452.0^{\mathrm{efA}}$ & $298.5^{\mathrm{fgB}}$ & $286.3^{\mathrm{eA}}$ & $294.8^{\mathrm{ghA}}$ & $182.9^{\mathrm{iB}}$ & $220.3^{\mathrm{gA}}$ \\
\hline C. collinum & $448.5^{\text {efgA }}$ & $354.8^{\operatorname{defB}}$ & $287.1^{\mathrm{eA}}$ & $284.8^{\text {ghiA }}$ & $162.1^{\mathrm{jB}}$ & $223.4^{\mathrm{gA}}$ \\
\hline D. melanoxylon & $557.2^{\mathrm{aA}}$ & $368.9^{\text {cdeB }}$ & $246.3^{\mathrm{fgA}}$ & $202.4^{\mathrm{kB}}$ & $215.6^{\mathrm{gA}}$ & $112.4^{\mathrm{jB}}$ \\
\hline G. monticola & $547.9^{\mathrm{abA}}$ & $509.1^{\mathrm{bA}}$ & $467.4^{\mathrm{aB}}$ & $502.3^{\mathrm{aA}}$ & $292.0^{\mathrm{bB}}$ & $320.0^{\mathrm{bA}}$ \\
\hline C. imberbe & $471.7^{\text {cdef } A}$ & $296.4^{\mathrm{gB}}$ & $279.8^{\text {efA }}$ & $231.7^{\mathrm{jB}}$ & $210.6^{\mathrm{gA}}$ & $89.0^{\mathrm{kB}}$ \\
\hline V. karroo & $522.3^{\mathrm{abcA}}$ & $575.9^{\mathrm{aA}}$ & $265.5^{\mathrm{efgB}}$ & $405.5^{\mathrm{cA}}$ & $244.7^{\mathrm{dA}}$ & $232.0^{\mathrm{fB}}$ \\
\hline O. kirkii & $464.5^{\operatorname{def} A}$ & $392.8^{\text {cdeB }}$ & $323.7^{\mathrm{dA}}$ & $273.5^{\mathrm{hB}}$ & $282.3^{\mathrm{cA}}$ & $114.3^{\mathrm{jB}}$ \\
\hline M. azedarach & $392.6^{\mathrm{gA}}$ & $338.2^{\text {efgA }}$ & $330.9^{\mathrm{cdA}}$ & $319.9^{\mathrm{efA}}$ & $223.2^{\mathrm{fA}}$ & $192.8^{\mathrm{hB}}$ \\
\hline S. nigrescens & $572.1^{\mathrm{aA}}$ & $422.8^{\mathrm{cB}}$ & $461.2^{\mathrm{aA}}$ & $402.0^{\mathrm{cB}}$ & $321.0^{\mathrm{aA}}$ & $310.7^{\mathrm{cB}}$ \\
\hline V. nilotica & $483.5^{\text {cdef } \mathrm{A}}$ & $370.0^{\mathrm{cdeB}}$ & $375.5^{\mathrm{bcA}}$ & $354.1^{\mathrm{dA}}$ & $325.2^{\mathrm{aA}}$ & $260.5^{\mathrm{eB}}$ \\
\hline G. occidentalis & $473.1^{\text {cdef } A}$ & $407.3^{\mathrm{cdB}}$ & $321.9^{\mathrm{dA}}$ & $225.3^{\mathrm{jkB}}$ & $203.0^{\mathrm{hA}}$ & $121.7^{\mathrm{iB}}$ \\
\hline Z. mucronata & $484.7^{\mathrm{cdeA}}$ & $338.4^{\text {efgB }}$ & $317.2^{\mathrm{dA}}$ & $302.8^{\mathrm{fgA}}$ & $216.5^{\mathrm{gB}}$ & $260.7^{\mathrm{eA}}$ \\
\hline B. zeyheri & $496.4^{\text {bcdeA }}$ & $283.0^{\mathrm{gB}}$ & $326.8^{\mathrm{dA}}$ & $263.5^{\mathrm{iB}}$ & $251.1^{\mathrm{dA}}$ & $222.2^{\mathrm{gB}}$ \\
\hline SE & 20.20 & & 8.12 & & 2.33 & \\
\hline
\end{tabular}

$\overline{\text { abcdefghij }}$ Shared lower case superscript letters within a column indicates a non-significant difference between browse species $(p>0.05)$

${ }^{\mathrm{AB}}$ Shared lower case superscript letters within a row indicates a non-significant difference between seasons $(p>0.05)$

$N D F$, neutral detergent fibre; $A D F$, acid detergent fibre; $A D L$, lignin detergent fibre; $S E$, standard error

concentrations higher than the minimum level in both seasons (above $85 \mathrm{~g} / \mathrm{kg} \mathrm{DM} /$ day in goats during maintenance stage) (NRC, 2000) and they can have the potential to be used as a protein supplement to grass-based diets. Neutral detergent fibre (NDF) content for the browse leaves ranged between 283.0 and $575.9 \mathrm{~g} / \mathrm{kg}$ DM, with summer tending to be generally much higher than winter except for $D$. cinerea. This finding was in line with Fentahun et al. (2020) who also reported a higher NDF concentration for the browse in dry seasons than in rainy seasons. The NDF concentration in winter is higher than summer because of the high intensity of solar radiation and the less amount of rainfall caused faster maturation during the winter season, of which it resulted in higher cell wall contents than those in the summer season (Aruwayo \& Adeleke, 2019). Low NDF concentration on $M$. azedarach and B. zeyheri (392.6 g/kg DM and $283 \mathrm{~g} / \mathrm{kg} \mathrm{DM}$, respectively) in both seasons is within the recommended ones for browsers and grazers (30-40\% DM) and this can have a direct relationship with DMI (Van Saun, 2016). The significance of DM intake lies in the utilization of forage by the animal and it is a determining factor of energy and performance in ruminants. The ADF results in this study were within a range of $202.4-502.3 \mathrm{~g} / \mathrm{kg}$ $\mathrm{DM}$ and this was within the range of that reported by Gemeda \& Hassen (2015) (273.3-495.1 g/kg DM) and lower than that reported by Anele et al. (2008) (604-607 g/kg DM). Saleem et al. (2012) agrees that the ADF concentration level in browse species can positively or negatively affect the digestibility. The lignin content in most of the browse species in our study were ranging between 89 to $355.8 \mathrm{~g} / \mathrm{kg} \mathrm{DM}$ for both seasons and was much higher in summer than in the winter season. Tjelele (2007) reported similar findings highlighting that lignin content in browse leaves varies based on the season, such that in warmer temperatures (summer) the lignin content increases and in lower temperatures (winter) lignin content decreases because 
Table 4 Effect of species and season on dry matter intake (kg/day), dry matter digestibility (\%) and total digestible nutrients (\%) of browse species found in semi-arid rangelands of South Africa

\begin{tabular}{|c|c|c|c|c|c|c|}
\hline & DMI & & DMDigest & & TDN & \\
\hline Species & Summer & Winter & Summer & Winter & Summer & Winter \\
\hline B. mollis & $13.9^{\mathrm{B}}$ & $16.2^{\text {bcdeA }}$ & $55.5^{\mathrm{hA}}$ & $55.6^{\mathrm{deA}}$ & $50.2^{\mathrm{hB}}$ & $61.2^{\text {efA }}$ \\
\hline D. cinerea & $12.7^{\mathrm{A}}$ & $12.5^{\operatorname{efg} A}$ & $69.9^{\mathrm{bcA}}$ & $43.1^{\mathrm{gB}}$ & $64.1^{\mathrm{cdA}}$ & $48.2^{\mathrm{iB}}$ \\
\hline B. maughamii & $10.9^{\mathrm{B}}$ & $13.6^{\operatorname{defgA}}$ & $58.2^{\mathrm{gB}}$ & $61.8^{\mathrm{bcA}}$ & $52.7^{\mathrm{gB}}$ & $67.6^{\mathrm{cdA}}$ \\
\hline B. discolor & $12.0^{\mathrm{B}}$ & $18.0^{\mathrm{abcdA}}$ & $66.6^{\mathrm{dA}}$ & $60.3^{\mathrm{cB}}$ & $60.9^{\mathrm{eB}}$ & $66.0^{\mathrm{dA}}$ \\
\hline C. collinum & $12.0^{\mathrm{B}}$ & $18.3^{\mathrm{abcA}}$ & $76.3^{\mathrm{aA}}$ & $57.5^{\mathrm{dB}}$ & $70.2^{\mathrm{aA}}$ & $63.1^{\mathrm{eB}}$ \\
\hline D. melanoxylon & $9.7^{\mathrm{B}}$ & $14.6^{\text {bcdefA }}$ & $69.7^{\mathrm{cdA}}$ & $67.2^{\mathrm{aB}}$ & $63.9^{\mathrm{cdB}}$ & $73.1^{\mathrm{aA}}$ \\
\hline G. monticola & $10.0^{\mathrm{A}}$ & $10.6^{\mathrm{fgA}}$ & $52.5^{\mathrm{iA}}$ & $44.6^{\mathrm{gB}}$ & $47.3^{\mathrm{iB}}$ & $49.8^{\mathrm{iA}}$ \\
\hline C. imberbe & $11.5^{\mathrm{B}}$ & $18.2^{\mathrm{abcA}}$ & $68.7^{\mathrm{cdA}}$ & $65.0^{\mathrm{aB}}$ & $62.9^{\mathrm{deB}}$ & $70.9^{\mathrm{bA}}$ \\
\hline V. karroo & $10.3^{\mathrm{A}}$ & $9.4^{\mathrm{gA}}$ & $68.2^{\mathrm{cdA}}$ & $51.9^{\mathrm{fB}}$ & $62.4^{\mathrm{deA}}$ & $57.3^{\mathrm{gB}}$ \\
\hline O. kirkii & $12.1^{\mathrm{A}}$ & $14.2^{\text {cdefA }}$ & $63.7^{\mathrm{eA}}$ & $61.8^{\mathrm{bcB}}$ & $58.1^{\mathrm{fB}}$ & $67.6^{\mathrm{cdA}}$ \\
\hline M. azedarach & $13.8^{\mathrm{B}}$ & $16.9^{\text {abcdeA }}$ & $71.5^{\mathrm{bcA}}$ & $57.0^{\mathrm{dB}}$ & $65.6^{\mathrm{cA}}$ & $62.6^{\mathrm{eB}}$ \\
\hline S. nigrescens & $9.4^{\mathrm{B}}$ & $12.8^{\mathrm{efgA}}$ & $53.0^{\mathrm{iA}}$ & $52.2^{\mathrm{fA}}$ & $47.7^{\mathrm{iB}}$ & $57.6^{\mathrm{gA}}$ \\
\hline V. nilotica & $11.2^{\mathrm{B}}$ & $15.3^{\text {bcdeA }}$ & $63.6^{\mathrm{eA}}$ & $54.6^{\mathrm{eB}}$ & $57.9^{\mathrm{fB}}$ & $60.1^{\mathrm{fA}}$ \\
\hline G. occidentalis & $11.4^{\mathrm{A}}$ & $13.3^{\text {efgA }}$ & $63.8^{\mathrm{eB}}$ & $65.5^{\mathrm{aA}}$ & $58.2^{\mathrm{fB}}$ & $71.4^{\mathrm{abA}}$ \\
\hline Z. mucronata & $11.1^{\mathrm{B}}$ & $20.7^{\mathrm{aA}}$ & $72.0^{\mathrm{bA}}$ & $56.9^{\mathrm{dB}}$ & $66.1^{\mathrm{bA}}$ & $62.5^{\mathrm{eB}}$ \\
\hline B. zeyheri & $10.9^{\mathrm{B}}$ & $19.1^{\mathrm{abA}}$ & $63.4^{\mathrm{eA}}$ & $62.6^{\mathrm{bA}}$ & $57.8^{\mathrm{fB}}$ & $68.4^{\mathrm{cA}}$ \\
\hline SE & 0.81 & & 0.40 & & 0.39 & \\
\hline
\end{tabular}

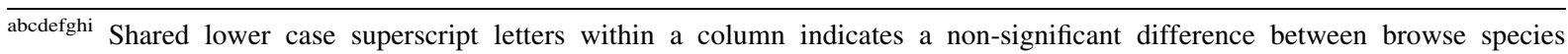
$(p>0.05)$

AB Shared lower case superscript letters within a row indicates a non-significant difference between seasons $(p>0.05)$

DMDigest, dry matter digestibility; DMI, dry matter intake; TDN, total digestible nutrients; SE, standard error

of limited light for plant development. Mokoboki et al. (2019) stated that lignin has an ability to reduce the nitrogen balance of animals by increasing endogenous and microbial nitrogen loss in faeces. Moreover, when plants have lower ADL level, the microflora is able to properly break down the low lignified leaves in the digestive tract of the ruminant because it is not resistant to chemical and enzymatic degradation (Ramantsi et al., 2020).

The digestibility of the substrates is normally influenced by the amount of ADF and most of the species had higher DM digestibility in summer when compared to winter. The DMDigest results in this study were ranging from 52.5 to $76.3 \mathrm{~g} / \mathrm{kg} \mathrm{DM}$ in summer and $43.1-67.2 \mathrm{~g} / \mathrm{kg} \mathrm{DM}$ in winter. Factors that may influence the variation of digestibility among woody species include nitrogen, cell wall content, lignin and bioactive compounds (Mlambo et al., 2015). It is essential to understand the manner in which ruminants use ME for their metabolizable functions due to their different efficiencies that are based on their nutritional requirements including their physiological stage (pregnancy, gestation, growth) and general maintenance (Filho et al., 2011). The ME of the studied species ranged between 1.91 and 2.79 $\mathrm{Mcal} / \mathrm{kg}$. Most browse species in this study had lower ME values in summer than in winter, this result is lower than that reported by Nsubuga et al. (2020) (above $3 \mathrm{Mcal} / \mathrm{kg}$ ). The ME of these species shows that they can be able to support the maintenance and high activity of goats $(0.57-2.78 \mathrm{Mcal} / \mathrm{kg})$ and other livestock such as dairy and beef cattle (NRC, 1985).

\section{In vitro dry matter degradability}

A lot of research has given a detailed account on the nutritive value and degradability of browse leaves (Ramantsi et al., 2020; Ravhuhali et al. 2020). The latter authors added that rumen degradability is capable of reaching up to $>600 \mathrm{~g} / \mathrm{kg}$ when there is 
Table 5 Effect of species and season on relative feeding value (g/kg DM), digestible energy (Mcal/kg) and metabolizable energy $(\mathrm{Mcal} / \mathrm{kg}$ ) of browse species found in semi-arid rangelands of South Africa

\begin{tabular}{|c|c|c|c|c|c|c|}
\hline & RFV & & $\mathrm{DE}$ & & ME & \\
\hline Species & Summer & Winter & Summer & Winter & Summer & Winter \\
\hline B. mollis & $769.7^{\text {abcdeB }}$ & $988.7^{\mathrm{bcA}}$ & $2.6^{\mathrm{hB}}$ & $2.9^{\mathrm{fgA}}$ & $2.2^{\mathrm{iB}}$ & $2.4^{\mathrm{deA}}$ \\
\hline D. cinerea & $891.4^{\mathrm{abcB}}$ & $600.7^{\mathrm{dB}}$ & $3.3^{\mathrm{bcdB}}$ & $2.3^{\mathrm{iA}}$ & $2.7^{\mathrm{cA}}$ & $1.9^{\mathrm{gB}}$ \\
\hline B. maughamii & $631.4^{\mathrm{cdeB}}$ & $917.9^{\mathrm{bcA}}$ & $2.8^{\mathrm{gB}}$ & $3.2^{\mathrm{cdA}}$ & $2.3^{\mathrm{hB}}$ & $2.6^{\mathrm{cA}}$ \\
\hline B. discolor & $796.5^{\mathrm{abcdB}}$ & $1189.8^{\mathrm{abA}}$ & $3.1^{\mathrm{eA}}$ & $3.1^{\mathrm{dA}}$ & $2.6^{\mathrm{fA}}$ & $2.5^{\mathrm{cA}}$ \\
\hline C. collinum & $918.4^{\mathrm{abB}}$ & $1151.2^{\mathrm{abA}}$ & $3.5^{\mathrm{aA}}$ & $3.0^{\mathrm{eB}}$ & $2.9^{\mathrm{aA}}$ & $2.4^{\mathrm{dB}}$ \\
\hline D. melanoxylon & $675.7^{\text {bcdeB }}$ & $1070.5^{\mathrm{abA}}$ & $3.3^{\mathrm{cdB}}$ & $3.4^{\mathrm{aA}}$ & $2.7^{\mathrm{cdB}}$ & $2.8^{\mathrm{aA}}$ \\
\hline G. monticola & $526.3^{\mathrm{deA}}$ & $527.9^{\mathrm{dA}}$ & $2.5^{\mathrm{iA}}$ & $2.4^{\mathrm{iB}}$ & $2.1^{\mathrm{jA}}$ & $2.0^{\mathrm{gB}}$ \\
\hline C. imberbe & $787.1^{\mathrm{abcdB}}$ & $1290.7^{\mathrm{aA}}$ & $3.2^{\mathrm{deB}}$ & $3.3^{\mathrm{bA}}$ & $2.6^{\mathrm{deB}}$ & $2.7^{\mathrm{bA}}$ \\
\hline V. karroo & $705.3^{\text {abcdeA }}$ & $537.6^{\mathrm{dB}}$ & $3.2^{\mathrm{deA}}$ & $2.7^{\mathrm{hB}}$ & $2.6^{\mathrm{eA}}$ & $2.2^{\mathrm{fB}}$ \\
\hline O. kirkii & $767.8^{\text {abcdeB }}$ & $961.9^{\mathrm{bcA}}$ & $3.0^{\mathrm{fB}}$ & $3.2^{\mathrm{cdA}}$ & $2.5^{\mathrm{gB}}$ & $2.6^{\mathrm{cA}}$ \\
\hline M. azedarach & $983.6^{\mathrm{aA}}$ & $1057.0^{\mathrm{abA}}$ & $3.3^{\mathrm{bcA}}$ & $3.0^{\mathrm{efB}}$ & $2.7^{\mathrm{bA}}$ & $2.4^{\mathrm{dB}}$ \\
\hline S. nigrescens & $500.2^{\mathrm{eB}}$ & $735.5^{\mathrm{cdA}}$ & $2.5^{\mathrm{iB}}$ & $2.7^{\mathrm{hA}}$ & $2.1^{\mathrm{jB}}$ & $2.3^{\mathrm{fA}}$ \\
\hline$V$. nilotica & $710.0^{\text {abcdeB }}$ & $916.7^{\mathrm{bcA}}$ & $3.0^{\mathrm{fA}}$ & $2.8^{\mathrm{gB}}$ & $2.5^{\mathrm{gA}}$ & $2.3^{\mathrm{eB}}$ \\
\hline G. occidentalis & $728.5^{\text {abcdeB }}$ & $946.0^{\mathrm{bcA}}$ & $3.0^{\mathrm{fB}}$ & $3.3^{\mathrm{abA}}$ & $2.5^{\mathrm{gB}}$ & $2.7^{\mathrm{abA}}$ \\
\hline Z. mucronata & $802.6^{\mathrm{abcdB}}$ & $1295.5^{\mathrm{aA}}$ & $3.4^{\mathrm{bA}}$ & $3.0^{\mathrm{fB}}$ & $2.8^{\mathrm{bA}}$ & $2.4^{\mathrm{dB}}$ \\
\hline B. zeyheri & $690.1^{\mathrm{bcdB}}$ & $1306.5^{\mathrm{aA}}$ & $3.0^{\mathrm{fB}}$ & $3.2^{\mathrm{cA}}$ & $2.5^{\mathrm{gB}}$ & $2.6^{\mathrm{cA}}$ \\
\hline SE & 50.09 & & 0.02 & & 0.01 & \\
\hline
\end{tabular}

$\overline{\text { abcdefghij }}$ Shared lower case superscript letters within a column indicates a non-significant difference between browse species $(p>0.05)$

${ }^{\mathrm{AB}}$ Shared lower case superscript letters within a row indicates a non-significant difference between seasons $(p>0.05)$

$R F V$, relative feeding value; $D E$, digestible energy; $M E$, metabolizable energy; $S E$, standard error

a higher concentration of $\mathrm{CP}$ than fibres in the feed diet. According to Fentahun et al. (2020) a high to medium DM degradability suggests that there is great value in feeding these browse species to livestock mostly in the winter season. The degradability of browse species increased with an increase in the incubation time meaning that it needs more time to be broken down by microbes which maybe a result of its high fibre contents of the species. Indeed, various extent and rate at which tropical browse species respond to rumen degradability is expected because of their different chemical composition profile and the season (Ma et al., 2019). The degradability was ranging from 315.1 to $605.7 \mathrm{~g} / \mathrm{kg} \mathrm{DM}$ (summer) and 223.1 to $611.6 \mathrm{~g} / \mathrm{kg} \mathrm{DM}$ (winter). In vitro DM degradability of this study was within Belachew et al. (2013) for tropical species leaves $(264.6-824.9 \mathrm{~g} / \mathrm{kg} \mathrm{DM})$, of which it is sufficient enough to satisfy the energy demands of less productive animals with lower production levels (Mokoboki et al., 2005). Even though in this study, tannins and phenolics were not studied, we cannot shy away from the association of lignin and tannin concentrations and their influence on effectively reducing the fermentation and digestion of the browse leaves (Gemeda \& Hassen, 2015).

\section{Conclusions}

Results from the current study, indicate that seasonal dynamics on browse species have an effect on the nutritive value, chemical estimates and in vitro dry matter degradability of indigenous woody species. In both seasons, most of these browse species have the potential to supplement low quality natural grasses because they go beyond the minimum requirement of protein and have reasonable amounts of fibre concentration. The overall assessment of these species indicates their outstanding nutritive traits which make 
Table 6 Effect of species and season on the in vitro dry matter degradability (DMD g/kg) (DMD24, DMD36, DMD48) of browse species found in semi-arid rangelands of South Africa

\begin{tabular}{|c|c|c|c|c|c|c|}
\hline & DMD24 & & DMD36 & & DMD48 & \\
\hline Species & Summer & Winter & Summer & Winter & Summer & Winter \\
\hline B. mollis & $268.1^{\mathrm{efgA}}$ & $263.6^{\mathrm{efgA}}$ & $298.0^{\mathrm{ghB}}$ & $339.7^{\mathrm{deA}}$ & $355.5^{\text {fghiA }}$ & $356.0^{\text {efgA }}$ \\
\hline D. cinerea & $248.4^{\mathrm{fgA}}$ & $213.4^{\mathrm{fgA}}$ & $270.4^{\mathrm{hA}}$ & $226.8^{\mathrm{fB}}$ & $338.0^{\text {ghiA }}$ & $260.9^{\mathrm{ghB}}$ \\
\hline B. maughamii & $374.6^{\mathrm{bcdA}}$ & $376.3^{\mathrm{cA}}$ & $407.8^{\mathrm{deA}}$ & $425.1^{\mathrm{bcA}}$ & $466,9^{\text {bcdefgA }}$ & $449.9^{\text {bcdefA }}$ \\
\hline B. discolor & $524.5^{\mathrm{aA}}$ & $468.4^{\mathrm{aB}}$ & $536.1^{\mathrm{abA}}$ & $515.7^{\mathrm{aA}}$ & $581.5^{\mathrm{abA}}$ & $556.0^{\mathrm{abcA}}$ \\
\hline C. collinum & $353.1^{\text {bcdeB }}$ & $404.8^{\mathrm{abcA}}$ & $380.4^{\mathrm{defB}}$ & $426.8^{\mathrm{bcA}}$ & $449.4^{\text {cdefghA }}$ & $472.9^{\text {bcdeA }}$ \\
\hline D. melanoxylon & $312.8^{\mathrm{cdeB}}$ & $464.5^{\mathrm{abA}}$ & $316.7^{\text {fghB }}$ & $487.3^{\mathrm{abA}}$ & $362.7^{\text {efghiB }}$ & $504.2^{\mathrm{abcdA}}$ \\
\hline G. monticola & $225.8^{\mathrm{gA}}$ & $185.0^{\mathrm{gA}}$ & $243.6^{\mathrm{hA}}$ & $194.7^{\mathrm{fB}}$ & $326.8^{\text {efghiA }}$ & $223.1^{\mathrm{hB}}$ \\
\hline C. imberbe & $366.4^{\mathrm{bcdA}}$ & $379.3^{\mathrm{bcA}}$ & $354.6^{\mathrm{efgB}}$ & $411.6^{\mathrm{bcdA}}$ & $403.4^{\text {defghiA }}$ & $452.9^{\text {bcdefA }}$ \\
\hline V. karroo & $255.6^{\mathrm{fgA}}$ & $272.4^{\operatorname{def} A}$ & $294.5^{\mathrm{ghB}}$ & $346.2^{\text {cdeA }}$ & $347.5^{\text {ghiB }}$ & $444.2^{\text {bcdefA }}$ \\
\hline O. kirkii & $475.2^{\mathrm{aA}}$ & $471.7^{\mathrm{aA}}$ & $507.7^{\mathrm{abcA}}$ & $534.8^{\mathrm{aA}}$ & $559.8^{\mathrm{abcA}}$ & $611.6^{\mathrm{aA}}$ \\
\hline M. azedarach & $497.7^{\mathrm{aA}}$ & $351.2^{\mathrm{cdB}}$ & $537.5^{\mathrm{aB}}$ & $404.3^{\mathrm{cdA}}$ & $605.7^{\mathrm{aA}}$ & $434.2^{\text {cdefB }}$ \\
\hline S. nigrescens & $256.5^{\mathrm{fgA}}$ & $269.3^{\operatorname{defg} A}$ & $299.8^{\text {fghA }}$ & $319.0^{\mathrm{eA}}$ & $344.0^{\mathrm{ghiA}}$ & $373.0^{\text {efgA }}$ \\
\hline$V$. nilotica & $292.8^{\operatorname{defg} \mathrm{A}}$ & $246.1^{\mathrm{fgB}}$ & $297.2^{\mathrm{ghA}}$ & $318.8^{\mathrm{eA}}$ & $315.1^{\mathrm{iA}}$ & $329.0^{\mathrm{fghA}}$ \\
\hline G. occidentalis & $384.5^{\mathrm{bcA}}$ & $374.9^{\mathrm{cA}}$ & $417.2^{\mathrm{deA}}$ & $386.0^{\text {cdeA }}$ & $483.3^{\text {abcdefA }}$ & $444.6^{\text {bcdefA }}$ \\
\hline Z. mucronata & $352.7^{\text {bcdeA }}$ & $339.6^{\mathrm{cdeA}}$ & $432.3^{\text {cdeA }}$ & $369.0^{\mathrm{cdeB}}$ & $492.2^{\mathrm{abcdeA}}$ & $404.1^{\operatorname{defB}}$ \\
\hline B. zeyheri & $438.5^{\mathrm{abA}}$ & $428.1^{\mathrm{abcA}}$ & $455.1^{\mathrm{bcdB}}$ & $529.2^{\mathrm{aA}}$ & $516.4^{\mathrm{abcdA}}$ & $567.4^{\mathrm{abA}}$ \\
\hline SE & 15.38 & & 14.50 & & 23.18 & \\
\hline
\end{tabular}

$\overline{\text { abcdefghi }}$ Shared lower case superscript letters within a column indicates a non-significant difference between browse species $(p>0.05)$

AB Shared lower case superscript letters within a row indicates a non-significant difference between seasons $(p>0.05)$; $D M D 24$, in vitro dry matter degradability at $24 \mathrm{~h} ; D M D 36$, in vitro dry matter degradability at $36 \mathrm{~h}$; DMD48, in vitro dry matter degradability at $48 \mathrm{~h} ; S E$, standard error

them suitable for their use in ruminant diets and can be given first preference for ruminants to browse them. Further studies need to be taken to investigate the level of bioactive compounds found in these woody species for amelioration and maximizing browsing of these species.

Acknowledgements Authors would like to acknowledge the North West University for the use of laboratories.

\section{Declarations}

Conflict of interest The authors declare no conflict of interest.

Open Access This article is licensed under a Creative Commons Attribution 4.0 International License, which permits use, sharing, adaptation, distribution and reproduction in any medium or format, as long as you give appropriate credit to the original author(s) and the source, provide a link to the Creative Commons licence, and indicate if changes were made. The images or other third party material in this article are included in the article's Creative Commons licence, unless indicated otherwise in a credit line to the material. If material is not included in the article's Creative Commons licence and your intended use is not permitted by statutory regulation or exceeds the permitted use, you will need to obtain permission directly from the copyright holder. To view a copy of this licence, visit http://creativecommons.org/licenses/by/4.0/.

\section{References}

Abebe A, Tolera A, Holand $\varnothing$, Ådnøy T, Eik LO (2012) Seasonal variation in nutritive value of some browse and grass species in Borana rangeland. Southern Ethiopia Trop Subtrop Agroecosyst 15(2):261-271

Aganga AA, Omphile UJ, Chabo RG, Kgosimore M, Mochankana M (2005) Goat production under traditional management in Gaborone agricultural region in Botswana. J Anim Vet Adv 4:515-519

Anele UY, Arigbede OM, Olanite JA, Adekunle IO, Jolaosho AO, Onifade OS, Oni AO (2008) Early growth and seasonal chemical composition of three indigenous multipurpose tree species (MPTS) in Abeokuta, Nigeria. Agrofor Syst 73:89-98 
AOAC (Association of Official Analytical Chemists) (1999) Official methods of analysis of AOAC International, 16th edn. AOAC, Arlington, VA

Aruwayo A, Adeleke RA (2019) A Review of Chemical Constituents and Use of Browse Plants in the Tropics. FUDMA Rec Chem Sci 1:1-11

Bath DL, Marble VL (1989) Testing alfalfa for its feeding value. Leafl. 21437. WREP 109. Div Agric Nat Resour Oakland Cal University Carlifonia USA

Belachew Z, Yisehak K, Taye T, Janssens GPJ (2013) Chemical composition and in sacco ruminal degradation of tropical trees rich in condensed tannins. Czech J Anim Sci 58:176-192. https://doi.org/10.17221/6712-cjas

Boufennara S, Lopez S, Bousseboua H, Bodas R, Bouazza L (2012) Chemical composition and digestibility of some browse plant species collected from Algerian arid rangelands. Spanish J Agr Res 10:88-98

Castro M, Teixeira A, Fernández-Núñez E (2021) The nutritive value of different Mediterranean browse species used as animal feeds under oak silvopastoral systems in Northern Portugal. Agroforest Syst 95:269-278

El Hassan SM, Halloo Kisi A, Newbolt CJ, Wallace RJ (2000) Chemical composition and degradation characteristics of foliage of some African multi-purpose trees. Anim Feed Sci Tech 86:27-37

Enahoro D, Croz DM, Mul M, Rich KM, Robinson TP, Thornton P, Staal SS (2019) Supporting sustainable expansion of livestock production in South Asia and SubSaharan Africa: Scenario analysis of investment options. Glob Food Sec 20:114-121

Federation of Animal Sciences Societies. 2010. "Guide for The Care and Use of Agricultural Animals in Research and Teaching." 3 ed., FASS: IIIinois, USA.

Fentahun S, Urge M, Mekuriaw Y (2020) Seasonal variation in Nutritional value of major browse species in North. J Plant Biotechnol 3:1-7

Filho JGLR, Pereira ES, Villarroel ABS, Pimentel PG, Fontenele RM, Costa MRGF, Maia ISG, Sombra WA (2011) Efficiency of metabolizable energy utilization for maintenance and gain and evaluation of small ruminant nutrition system model in Santa Ines sheep. Rev Bras Zootec 40:2558-2564

Fonnesbeck PV, Clark DH, Garret WN, Speth CF (1984) Predicting energy utilization from alfalfa hay from the Western Region. In: Proceedings of the 2002 Cornell Nutrition Conference for Feed Manufacture, East Syracuse, NY. Ithaca, NY: Cornell University USA

Gemeda B, Hassen A (2015) Effect of tannin and species variation on in vitro digestibility, gas, and methane production of tropical browse plants. Asian-Australas J Anim Sci 28:188-199

Hassen A, Rethman NFG, van Niekerk WA, Tjelele TJ (2007) Influence of season/year and species on chemical composition and in vitro digestibility of five Indigofera accessions. Anim Feed Sci Technol 136:312-322

Hassen A, Tessema ZK, Tolera A (2017) Seasonal variations in chemical composition, in vitro digestibility and ruminal degradation of browse species in the Rift Valley of Ethiopia. Livest Res Rural Dev 29:112
Jeranyama P, Garcia AD (2004) Understanding relative feed value (RFV) and relative forage quality (RFQ). Cooperative Extension Service. SD, USD South Dakota USA

Kababya D, Perevolotsky A, Bruckental I, Landau S (1998) Selection of diets by dual-purpose Mamber goats in Mediterranean woodland. J Agric Sci Camb 131:221-228

Khalil JK, Sawaya WN, Hyder SZ (1986) Nutrient composition of Atriplex leaves grown in Saudi Arabia. J Range Mana 39:104-107

Ma L, Xu S, Liu H, Xu T, Hu L, Zhao N, Han X, Zhang X (2019) Yak rumen microbial diversity at different forage growth stages of an alpine meadow on the Qinghai-Tibet Plateau. Peer J 1-27

Mertens DR (2002) Physical and chemical characteristics of fiber affecting dairy cow performance. In: Proceedings of the 2002 Cornell Nutrition Conference for Feed Manufacture. East Syracuse, NY. Ithaca, NY: Cornell University pp 125-144

Minson DJ (1990) Forage in ruminant nutrition. Academic Press, London

Mlambo V, Marume U, Gajana CS (2015) Utility of the browser's behavioural and physiological strategies in coping with dietary tannins: Are exogenous tannin-inactivating treatments necessary? S Afr J Anim Sci 45:441-451

Mokoboki HK, Ndlovu LR, Ng'ambi JW, Malatje MM, Nikolova RV (2005) Nutritive value of acacia tree foliages growing in the Limpopo province of South Africa. S Afr J Anim Sci 35:221-228. https://doi.org/10.4314/sajas.v35i4. 3963

Mokoboki HK, Sebola AN, Ravhuhali KE, Nhlane L (2019) Chemical composition, in vitro ruminal dry matter degradability and dry matter intake of some selected browse plants. Cogent Food Agric 5:1-10

Msiza NH, Ravhuhali KE, Mokoboki HK, Mavengahama S, Motsei LE (2021) Ranking species for veld restoration in semi-arid regions using agronomic, morphological and chemical parameters of selected grass species at different developmental stages under controlled environment. Agronomy 11:52. https://doi.org/10.3390/agronomy 11010052

Mudzengi, IP, Murwira A, Halimani T, Fritz H, Murungweni C (2020) Relationships between farmer perceptions and temporal variation in nutritive value of browse species on savanna rangelands, Afr.J Range For. Sci. 37(3): 237-242, DOI: https://doi.org/10.2989/10220119.2020.1779125

NRC (National Research Council) (1985) Nutrient requirements of domestic animals, no 5. Nutrients requirement of sheep, 6th edition. National Academic Science, Washington DC 112 USA

NRC (National Research Council) (2000) Nutrient requirements of beef cattle. 7th edition. Washington, DC

Nsubuga D, Kalule D, Muwanika VB, Masembe C (2020) Nutritional properties of some browse species used as goat feed in Pastoral dry lands, Uganda. Agrofor Syst 94:933-940. https://doi.org/10.1007/s10457-019-00452-x

Osuga IM, Abdulrazak SA, Muleke CI, Fujihara T (2012) Effect of supplementing Rhodes grass hay (Chloris gayana) with Berchemia discolor or Zizyphus mucronata on the performance of growing goats in Kenya. J Anim Physiol Anim Nutr (Berl) 96:634-639. https://doi.org/10.1111/j.14390396.2011.01189.x 
Ramantsi KR, Mnisi CM, Ravhuhali KE (2020) Chemical composition and in vitro dry matter degradability of mistletoe (Viscum verrucosum) (Harv.)) on Vachellia nilotica (L) in North West Province of South Africa. Trop Agric 96:53-60

Ravhuhali KE, Mlambo V, Beyene TS, Palamuleni LG (2020) Effects of soil type on density of trees and nutritive value of tree leaves in selected communal areas of South Africa. S Afr J Anim Sci 50:88-98

Ravhuhali KE, Ng'ambi JW, Norris D, Ayodele VI (2011) The feeding value of four cowpea hay cultivars and effect of their supplementation on intake and digestibility of buffalo grass hay fed to Pedi goats. Asian J Anim Vet Adv 6(9):909-922

Saleem NA, Nour ME, Adam KM, (2012) The nutritive value of leaves and fruits of three Grewia species under semi-arid environment. J Agric Sci Technol 2:956-964

SAS (2010) Statistical Analysis system. Statistics Software. Release 10 SAS Institute Inc Cary NC USA
SAWA (South African Weather Services) (2020) Centurion Pretoria, Gauteng Province South Africa. Accessed 23 Apr 2020

Tjelele TJ (2007) Dry matter production, intake and nutritive value of certain Indigofera species. $\mathrm{PhD}$ thesis, University of Pretoria, Pretoria, Gauteng province, South Africa

Van Saun RJ (2016) Determining forage quality; understanding feed analysis. Penn State Extension 3(8):18-26

Van Soest PJ, Robertson JB, Lewis BA (1991) Methods for dietary fiber, neutral detergent fiber, and nonstarch polysaccharides in relation to animal nutrition. J Dairy Sci 74:3583-3597

Van Wyk B, Van Wyk BE, Van Wyk P (2012) Photo Guide to Trees of South Africa. Briza publications, Pretoria South Africa

Publisher's Note Springer Nature remains neutral with regard to jurisdictional claims in published maps and institutional affiliations. 